\title{
When and how to treat patients who refuse treatment
}

This Practice article by Rosemary A Humphreys and colleagues (BMJ 2014;348:g2043, doi:10.1136/bmj.g2043) contains some errors in the following sections. A more detailed discussion of these issues can be viewed in the authors' rapid response to the online article (http://www.bmj.com/content/348/bmj.g2043/rr/ 698747).

In table 1, the "Criteria" for "Common law" should have read "Action is needed to prevent harm; in emergencies only," rather than "Action is needed to prevent harm; in emergencies only until there is time to assess capacity or undertake an MHA assessment" as was published. Also, under "MHA" the "Criteria" should have read: "The patient's mental disorder is of a nature (type) or [not "and" as published] degree (severity) that requires compulsory assessment or treatment in hospital." In the third row of figure 1 (algorithm), "Use common law" should have read "Use MCA (or common law)." In the fourth row, "Use frameworks of MHA or MCA (following step 2) once there is opportunity for assessment" should have read "Following step 2 use frameworks of MCA (if not already using) or MHA once there is opportunity for assessment." For clarity, both table 1 and figure 1 have been reproduced at the bottom of this page with their correct wording.

Finally, in the section "Step 1: how urgent is treatment? Is common law applicable?" the second sentence should be replaced with: "In such situations, despite there being insufficient time for a fuller capacity assessment, the MCA should be used. In emergencies the MCA Code of Practice acknowledges that there is a reduction in the time available, and subsequent expected level of capacity assessment required, to arrive at a 'reasonable belief' that capacity is lacking and to decide on what treatment, if any, is in the patient's best interests. However, there are a few important exceptions to this when common law is used, such as when the patient is under the age of 16 or when the intervention is for the protection of others; in such cases the MCA is not applicable (see Table)."

Cite this as: BMJ 2014;348:g3501

๑ BMJ Publishing Group Ltd 2014 


\section{Table}

Table 1 | Summary of key differences between common law, the Mental Capacity Act (MCA), Mental Health Act (MHA)*

\begin{tabular}{|c|c|c|c|}
\hline Aspect & Common law & MCA & MHA \\
\hline Disorders covered & Any disorder (physical or mental) & Disturbance in functioning of brain or mind & Any disorder or disability of the mind \\
\hline Criteria & $\begin{array}{l}\text { Action is needed to prevent harm; in } \\
\text { emergencies only }\end{array}$ & $\begin{array}{l}\text { The patient lacks capacity for a specific } \\
\text { treatment decision(s); applies only to } \\
\text { patients aged } 16 \text { years and over }\end{array}$ & $\begin{array}{l}\text { The patient's mental disorder is of a nature } \\
\text { (type) or degree (severity) that requires } \\
\text { compulsory assessment or treatment in } \\
\text { hospital }\end{array}$ \\
\hline Who it protects & Patient or others & Patient only & Patient or others \\
\hline Disorders that can be treated & Mental and physical health treatment & $\begin{array}{l}\text { Mental and physical treatment in patient's } \\
\text { best interests }\end{array}$ & Treatment of mental disorder only \\
\hline Limits of restraint $†$ & Emergencies only & $\begin{array}{l}\text { Deemed a necessary and proportionate } \\
\text { response to prevent harm to the patient }\end{array}$ & Involuntary detention in hospital \\
\hline $\begin{array}{l}\text { Important exclusions of } \\
\text { application }\end{array}$ & $\begin{array}{l}\text { Non-immediately life-threatening } \\
\text { situations where there is time to assess } \\
\text { capacity }\end{array}$ & $\begin{array}{l}\text { Cannot be used to treat patients under the } \\
\text { age of } 16 \text { years }\end{array}$ & $\begin{array}{l}\text { Cannot be used to treat physical } \\
\text { disorders unless it is causing the mental } \\
\text { illness or is a direct consequence of it } \\
\text { (discussed below) }\end{array}$ \\
\hline
\end{tabular}

*Important differences are highlighted in bold.

†Restraint should always be proportional and necessary. 


\section{Figure}

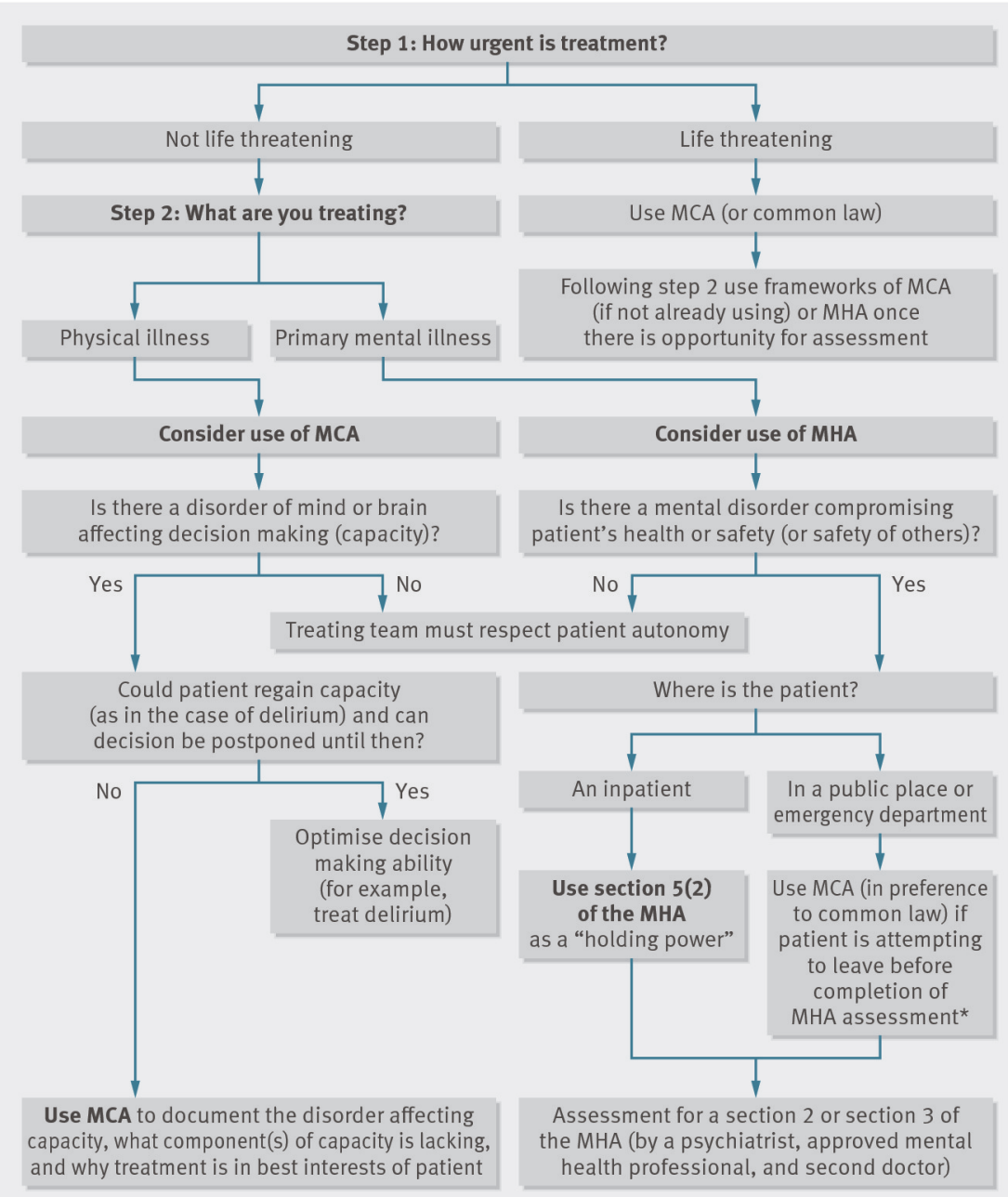

* Depending on local definitions of a 'place of safety' or a 'place to which public have access' police may use section 136 of the MHA to keep patient in an emergency department including subsequent transfer to a special facility within a psychiatric hospital (often referred to as a 's136 suite') 